NBER WORKING PAPER SERIES

\author{
FINANCIAL INNOVATION AND THE \\ MANAGEMENT AND REGULATION OF \\ FINANCIAL INSTITUTIONS
}

Robert C. Merton

Working Paper No. 5096

\author{
NATIONAL BUREAU OF ECONOMIC RESEARCH \\ 1050 Massachusetts Avenue \\ Cambridge, MA 02138 \\ April 1995
}

First presented at the Risk Management of Financial Institutions and the Role of Capital Conference, Wharton School, University of Pennsylvania, March 1994. Later versions presented at International Monetary Conference, London, June 1994 and the European Institute for Financial Analysis and Portfolio Management, Geneva, June 1994. To appear in Journal of Banking and Finance, 19(1995). I thank the participants for their helpful comments. Thanks also to Zvi Bodie, Peter Hancock, and Myron Scholes. Support from the Global Financial System project, Harvard Business School, is gratefully acknowledged. This paper is part of NBER's research programs in Asset Pricing, Corporate Finance, International Finance and Macroeconomics, and Monetary Economics. Any opinions expressed are those of the author and not those of the National Bureau of Economic Research.

(C) 1995 by Robert C. Merton. All rights reserved. Short sections of ext, not to exceed two paragraphs, may be quoted without explicit permission provided that full credit, including $\odot$ notice, is given to the source. 


\title{
FINANCIAL INNOVATION AND THE MANAGEMENT AND REGULATION OF FINANCIAL INSTITUTIONS
}

\begin{abstract}
New security designs, improvements in computer telecommunications technology and advances in the theory of finance have led to revolutionary changes in the structure of financial markets and institutions. This paper provides a functional perspective on the dynamics of institutional change and uses a series of examples to illustrate the breadth and depth of institutional change that is likely to occur. These examples emphasize the role of hedging versus equity capital in managing risk, the need for risk accounting and changes in methods for implementing both regulatory and stabilization public policy.
\end{abstract}

\author{
Robert C. Merton \\ Graduate School of Business Administration \\ Morgan 397 \\ Harvard University \\ Soldiers Field Road \\ Boston, MA 02163 \\ and NBER
}


Financial Innovation and the Management and

Regulation of Financial Institutions*

Robert C. Merton

Harvard University

\section{INTRODUCTION}

Risk management of financial institutions and the role of capital is a rich and topical subject from the perspectives of both academics and practitioners. However, my remarks here will not focus on either risk-based capital or deposit insurance or even the performance of financial institutions. ${ }^{1}$ Along those dimensions, it is clear from the agenda that we all will find our cups abundantly filled on these topics over the course of the conference. Instead, in this salutatory session, I try my hand at creating a frame of reference for what

-First presented at the Risk Management of Financial Institutions and the Role of Capital Conference, Wharton School, University of Pennsylvania, March 1994. Later versions presented at International Monetary Conference, London, June 1994 and the European Institute for Financial Analysis and Portfolio Management, Geneva, June 1994. To appear in Joumal of Banking and Finance, 19(1995). I thank the participants for their helpful comments. Thanks also to Zvi Bodie, Peter Hancock, and Myron Scholes. Support from the Global Financial System project, Harvard Business School, is gratefully acknowledged.

${ }^{1}$ The definition and measurement of risk capital and its distinction from either cash capital or regulatory capital is discussed in Merton and Perold (1993). 
is to follow by describing prospectively some of the changes in the evolving financial system and by addressing some supporting but potentially fundamental issues that lie underneath the topic focus of the conference.

Let me begin with a question: As we all know, the past twenty years have seen revolutionary changes in the structure of the world's financial markets and institutions and in our understanding of how to use them to provide new investment opportunities and ways of managing risk. ${ }^{2}$ Those financial innovations came about in part because of a wide array of new security designs, in part because of the advances in computer and telecommunications technology, and in part because of important advances in the theory of finance. ${ }^{3}$ Why then is there now such an intensity of concern by managers, regulators, politicians, and the press over the new activities and risks of financial institutions - relative to their traditional risks such as real estate loans or LDC debt? Certainly, there has not yet been a major financial crisis associated with these new activities and instruments of the kind associated with defaults by countries and the thrifts in the 1970s and 1980s. Indeed, as will be discussed in Section 4, the rise of derivative products could

\footnotetext{
${ }^{2}$ See Allen and Gale (1994), Finnerty (1992), Mason et al. (1995), Merton (1992a), Miller (1991), and Sanford (1993).

${ }^{3}$ See Bernstein (1992) for a carefully researched description of this interaction between theory and practice in bringing about some of the major innovations of the last few decades. Merton (1994) provides a brief overview on the role of mathematical models in finance practice.
} 
have just as easily been framed as greatly reducing risks in the system instead of increasing them. ${ }^{4}$

My conjecture as to why there is this anxiety or strong focus on the risks of the new activities is that their implementation has required major changes in the basic institutional hierarchy and in the infrastructure to support it and that the knowledge base required to manage this part of the system is significantly different from the traditional training and experience of many private-sector financial managers as well as regulators. Changes of this sort are threatening. It is difficult to deal with change that is exogenous with respect to our traditional knowledge base and framework and therefore seems outside of our control. Less apparent understanding of the new environment can create a sense of greater risk even if the objective level of risk in the system is unchanged or reduced. The case for this conjecture is explored indirectly in the sections to follow by discussing the institutional and knowledge-base changes needed in the areas of risk management, identification of risk categories, the accounting system, and methods for implementing both regulatory and stabilization public policy.

\footnotetext{
${ }^{4}$ It is all the more perplexing because derivative securities have long been integral parts of the financial system. As discussed in Merton (1992a,13), options, forward contracts, and futures have been around since the 17th and 18th Centuries in Europe, the United States, and Japan. Among the earliest derivative securities are bank currencles (money) which "derived" their value from their convertibility into the underlying gold held in depositories.
} 


\section{FINANCIAL INNOVATION AND RISK MANAGEMENT}

Looking at financial innovations - from the perspective of physiology rather than pathology - one sees them as the force driving the global financial system towards its goal of greater economic efficiency. In particular, innovations involving derivatives can improve efficiency by expanding opportunities for risk sharing, by lowering transaction costs and by reducing asymmetric information and agency costs.

Some see the extraordinary growth in derivatives securities over the past five years as only a fad. Indeed, a US Senator recently referred to it as "an electronic Ponzi scheme." However a more likely explanation for the enormous increases in derivative-trading volume is the vast savings in transaction costs from their use. ${ }^{5}$ The costs of implementing financial strategies for institutions using derivatives can be a tenth to a twentieth of the cost of using underlying cash-market securitles. Looking to the future with such costs savings, we are not going back. Derivatives are a permanent part of the main stream global financial system.

What about the pace of innovation in the future? We have certainly seen an extraordinary amount of innovation in the last two decades, and especially during the past one. Perhaps we need a rest, but as I see it, innovation is going to at least continue at the current pace and perhaps even accelerate. The reason for that belief is reduced costs and improving technology. I have in

\footnotetext{
${ }^{5}$ See Perold (1992) for cost comparisons of using derlvatives. See also Darby (1994).
} 
mind not just lower transaction costs but also the learning curve: when one has created nine new markets, the tenth one becomes a lot easier to do.

The rapid five-year growth in over-the-counter derivatives (which are transacted away from a central market putting greater pressure on the underlying institution capability to price those derivatives and manage their risk) reflects a growing confidence in the issuing institutions' modeling and evaluation skills. I think that confidence comes not just from improved technology, but from literally having used those types of models in real-world practice on a large scale for a considerable period of time. It is in that sense that cost reduction flows from moving down the learning curve. ${ }^{6}$

The total reduction in costs has the effect of reducing the threshold of benefit needed to cover the cost of a new innovation. If fundamental economic change and uncertainties continue to be of similar magnitude as in the past, then I would anticipate, because of the reduced costs, even greater financial innovation activity, particularly in the area of risk management. ${ }^{7}$

The key difference in future activity of innovation from the past will be that we will not only see many new products and new markets, but whole institutional structures changing, including their geo-political locations.

${ }^{6}$ This point is discussed further in Merton (1994).

${ }^{7}$ This "feedback" effect between innovation and cost reduction is part of the process underlying the "financial-innovation spiral." See Merton (1992a, 1993,1994). 
Therefore, we will see institutional change occurring in a way not seen in the past, both in scale and in speed.

This effect of institutional change will not be limited to private-sector financial institutions, but will also encompass public-sector government institutions that are associated with the financial markets. I have in mind particularly central banks, and the functions they serve and how they will serve them. Since institutions are for many the "anchors" which traditionally are used to organize thinking about financial activities involving evolution of the financial system, widespread and rapid changes in the institutions themselves can make this task especially difficult for financial managers, regulators and policymakers. As discussed in Section 3, an alternative perspective based on functions as the anchors may provide the means for handling institutional change as part of the analytical framework.

This paper uses a series of examples to illustrate the breadth and depth of institutional change that is likely to take place in the future. It will also tentatively describe a new set of conceptual anchors to replace those used now as a way of thinking about the dynamics of institutional change.

I begin in the area of risk management which has itself experienced rather remarkable innovation during the last decade. A thought which may be obvious but sometimes is not consciously considered is that when more opportunities for risk control flow from the technology, both financial managers 
and regulators must then decide what to do about it. When there were few choices, they had few decisions to make. Now they have multiple decisions to make and as a result face greater complexity.

The management of risk has traditionally focussed on capital. Equity capital is the "cushion" for absorbing risks of the institution. It is a wonderful, all-purpose cushion. Why? Because management need not know what the source of the unanticipated loss is. They do not have to predict the source of loss, because equity protects the firm against all forms of risk; it is in that sense an all-purpose cushion and thus it is very attractive for managing risk. As we all know, equity capital also can be quite expensive for exactly that reason. One can formally employ theories of agency cost, taxation and so forth to supply reasons why equity financing can be expensive. ${ }^{8}$

The other fundamental means for controlling risk is through hedging. In contrast to equity capital which is all-purpose, hedging is a form of risk control that is very targeted. For example, a manager of an international airline can use futures, forwards, or contractual agreements to hedge the firm against unexpected changes in jet fuel prices. More generally, managers hedge their firms against changes in commodity prices, interest rates, and currency exchange rates. To hedge, the firm must not only specify what kind of risk it is hedging but also the exact quantity of that risk. 
$-10-$

Hedging is a form of risk control that can be very efficient as a substitute for equity capital but it carries with it the requirement that its users have a deep quantitative understanding of their business. They must understand much more about their structures than in the case of all-purpose equity capital. Developing this deeper understanding of their business is going to require retraining of the ways managers think about their businesses if they are to use hedging effectively.

Consider for instance the example of a "synthetic refinery". Imagine a firm with extensive crude oil reserves and a chain of gasoline stations. Suppose that strategic analysis concludes that there are serious risk concerns about ensuring the firm's access to the production process which links those two activities together. The need to eliminate that risk in the past would have been satisfied by perhaps acquiring a refinery. (I do not think anybody builds them any more.) The alternative today, especially if the firm has no expertise in refining or managing a refinery, would be to enter into contracts in which the firm agrees to deliver so many barrels of crude oil and, perhaps with some time delay, receives in return so many of gallons of high-grade gasoline. That contract functionally creates a synthetic refinery. It may not be appropriate for 
every such firm but entering into a simple contract is perhaps a lot safer and a lot more efficient than acquiring the refinery itself. ${ }^{9}$

As the skills needed to apply these kinds of risk management are acquired by institutions and their customers, one of the outcomes for institutional change will not be in financial institutions but in non-financial firms. In particular, I have in mind the choice between being a private firm (by that I mean a firm with a relatively small number of owners) or being a public firm with ownership held by public shareholders.

Consider some of the trade-offs that one weighs when making the choice between the firm being private and public. The advantages of being private are headed by reduced agency costs, lower costs of transferring information including external reporting, protection of key information from competitors, and greater flexibility to optimize with respect to taxes and regulation.

What are the benefits of going public? Most important is the risksharing benefits. If a small group of owners is bearing the full risks of the firm, then at some point if this risk becomes large enough, the shadow price placed by them on the firm is lower than the public market price would be because they cannot achieve the diversification that public shareholders have. Hence, private owners internalize parts of the firm's risks which are diversifiable with

\footnotetext{
${ }^{9}$ For further real-world corporate applications, see Mason et al. (1995).
} 
widespread ownership. The other key benefit has to do with capital expansion. The private firm runs into limits on debt as a function of the absolute variability of the business. I underscore for those who may think in terms of systematic risk that the key measure of risk here is absolute or total volatility. Consider such a firm with needs for funding and risk sharing that believes it must move to the public-ownership domain with all its costs (that reflect what the firm gives up by going public). If the firm were instead able to use efficient hedging as risk management to strip away the risks of the business which are not adding to value (commodity price risks, interest rate risks, currency risks, ...), then it could reduce the total variation or riskiness of the business, without negatively impacting its profitability. In so doing, it reduces the risk exposure to its private owners. The reduced risk will also allow the firm to expand its capacity to raise capital in the debt market without going public. To the extent hedging becomes widespread, one may well observe a macro shift back toward greater private ownership of firms as these hedging tools are developed. This shift in institutional structure for firms marks one type of influence that financial innovation can have beyond the financial sector.

\section{DYNAMICS OF INSTITUTIONAL CHANGE}

Effective analysis of issues involving the global financial system of the future requires a conceptual framework that handles endogenously the 
differences in institutional structure across borders as well as the dynamics of institutional change. The dynamics of prices and quantities are covered by the neoclassical-economics paradigm. However, it is essentially an "institutionfree" perspective in which only functions matter. It therefore does not address cross-sectional or intertemporal differences in the institutions that serve those functions. In contrast, there is the institutional perspective in which the unit of analysis is the institution and the existing institutional structure is taken as a given. It is static in focus. Because institutions not only matter but are the conceptual anchor of this perspective, institutional change within this framework is exogenous.

Building on both of these perspectives, the functional perspective takes as given the economic functions served by financial institutions and searches for the best institutional structure to perform those functions at a given time and place. ${ }^{10}$ It does not assume that the existing mix of institutions remains the same. Instead, functions are the stable elements in this framework. Institutions matter but are not the anchors, and institutional changes are thus endogenous within this perspective.

\footnotetext{
${ }^{10}$ For more on functional analysis and the functional perspective, see Bodie and Merton (1993), Crane et al. (1995), Mason et al. (1995), Merton (1993), Merton and Bodie (1993), Pierce (1993), Sanford (1993), and Scholes (1994).
} 
The differences between the institutional and functional perspectives can be seen from a brief discussion of insurance. Institutionally, insurance companies produce insurance contracts but what function does insurance serve? It guarantees the value of an asset under specific circumstances. Note however that a put option issued by an options exchange also provides a guarantee of asset value. Both insurance contracts and put options serve the same function: namely, protection against loss in asset value. Nevertheless, the issuing institutions are entirely different: an options exchange is not an insurance company. Moreover, a put option traded on an exchange is a different product from an insurance contract. Although the products and the institutions that provide them are both quite different, functionally they do the same thing: provide a guarantee of asset value to the customer. Hence, either could be used as a substitute for the other.

To address the prospect for change in the institutional categories and classifications of risk, we develop a single example drawn from a stereotypical situation in asset management. Whether in the mutual-fund business, pension-fund business, or private banking, suppose that you are a manager of assets. Suppose further that your firm's special expertise is in the management of fixed-income assets. Perhaps in particular, your firm is a bank that has the facility for managing and understanding credit risks and therefore it has a special expertise in the area of evaluating corporate debt. We stipulate 
in the example here that the bank really does have the skills to outperform in that particular arena. In particular, assume that, on average, the bank asset managers are able to beat some standard corporate-bond index by 200 basis points, $2 \%$. In comes a potential client, a large pension plan sponsor. The client says; "I am looking for a superior-performing equities manager, someone to manage money for us in the area of stocks." In the past, responsible institutions would say to the client that: "We would be delighted to manage your money, but we have no skill in the equities area." Some irresponsible ones might take the money anyway. But not today. Today one can say; "But of course, we are indeed a superior equities manager." As a US example, suppose that the investment choice is between US corporate bonds, which is the asset class the bank is good at managing, and US equities, as represented by the S\&P 500 .

How can the bank become a superior equity manager when it has skills only in the fixed-income market? The client gives the bank a $\$ 100$ million to invest. The actual money goes into the bank's bond portfolio, which the bank managers know how to manage and earn a superior return. But since the client is looking for superior equity management, the bank also enters into a swap contract, described as follows: The contract states that the bank, representing the client's investment, will pay to a counterparty the total return on the corporate bond index each year on the basis as if it had $\$ 100$ million 
invested in it and, in return, the counterparty to that contract will pay the bank the total rate of return on the S\&P 500 stock index applied to $\$ 100$ million. That is the swap, a simple exchange of returns. By arbitrage, the price at which this contract would be struck is zero (except for transactions fees). Exchanging these returns is an even swap. Neither party would have to pay the other anything for entering into this contract.

What is the effect of having entered into this contract? The simple arithmetic follows: If indeed we are correct, that the $\$ 100$ million invested in the bank's corporate-bond fund earns, on average, the bond index plus $2 \%$, then the payout of the bond index as part of our agreement leaves the bank portfolio with just the $2 \%$ incremental return. However, the counterparty must pay to the bank in return whatever the S\&P 500 earns. Adding these components, we have that the net of the transaction investing in bonds which we know about, plus the swap contract which effectively costs nothing, is that the bank's client will earn the S\&P $500+2 \%$ on average. Hence, without any analyst skill directly in the equity market, by a simple contract, investment managers can transform themselves if they are a superior performer in some arena (and in this case, corporate bonds) into a superior performer in any other market, such as the equity market.

The intent of this example was not to generate new product ideas. Instead, it does point out an important potential efficiency gain for the 
management of financial services: Namely, that finance professionals and their firms can continue to specialize in what they are good at and not feel pressure to expand into areas in which they have no comparative advantage just so that they can offer a full range of products. This swap/contracting vehicle is a very efficient one for achieving such breadth.

A second intended message from this simple example is that some of our traditional institutional categories are becoming almost arbitrary. What does it mean to be called a "fixed-income manager" if one can convert oneself into a superior equity manager by a mere swap contract, or for that matter if one is superior in any area including cash management, then he can also make that transformation?

Think of the traditional institutional break-downs for asset-management categories. Once it is recognized that financial innovation has brought us to this point, not just as a theoretical concept but also as a practical reality, one must certainly begin to think about how to reorganize those institutional categories. In particular, where would our hypothetical bank locate the activity of the preceding example? In a typical organization, is it within "fixed income" or "equities"? Does it make sense to do either? Much the same story, by the way, applies to using geographical locations of assets as classifications: "European equities" versus "fixed income in Japan." Through a series of 
swaps, superior performances on one of those markets can be transformed into superior performance in any other.

Consider what the implications are not only for the management of financial-service firms, but for regulators with regulation that is organized along the lines of those traditional categories. I have in mind, for example (and do not take this as a criticism so much as just a description), the Bank for International Settlement ("BIS") international capital rules. Those rules, at least as I last understood them, were organized along categories of products or asset types. Very briefly, in the US for example, if a bank were managing and holding mortgages on houses, it would have to maintain a capital requirement of $4 \%$. If, instead, it were to continue operate in the mortgage market in terms of origination and servicing, but sell the mortgages and use the proceeds to buy US government bonds, then under the BIS rules, US government bonds produce no capital requirement and the bank would thus have no capital maintenance. However, the bank could receive the economic equivalent of holding mortgages by entering into an amortizing swap in which the bank receives the total return on mortgages, including the amortization features and prepayments and pays the returns on US Treasury bonds to the swap counterparty. The net of that series of transactions is that the bank receives the return on mortgages as if it had invested in them directly. However, the 
BIS capital calculation, instead of it being $4 \%$, appears to produce a capital requirement using the swap route of about $0.5 \%$.

Again, these remarks are not intended to be critical of those who set up those regulations. It is instead an attempt to underscore that fundamentally, many of those institutional categories (not only for institutions but for the very products themselves) will have to be redefined to be operationally effective in setting regulations. This is both frightening and exciting.

On the matter of institutional categories: could there be institutional categories "more institutional" than those in the system of accounting itself ? We have already seen that one can convert debt to equity and equity to debt. If there are any doubts about that, consider equity-linked notes which are bone fide debts institutionally, but in terms of a return pattern behave like equity. Or consider equity owners who have sold forward the return on their shares through a swap or some other vehicle, in which case they institutionally hold equities but in economic effect they have debt. ${ }^{11}$

A common accounting application is to use ratios to measure the financial health and riskiness of companies. One such ratio, leverage measured by assets-to-equity capital, is often pointed to as an indicator of risk. However, the leverage ratio has increasingly become less meaningful, especially

\footnotetext{
${ }^{11}$ For further discussion of the blurring distinction between debt and equity from different perspectives, see Kopeke and Rosengren (1990).
} 
for financial firms. As an illustration, consider an institution with $\$ 100$ in equity capital that buys bond $\mathrm{A}$ for $\$ 1000$ and borrows bond $\mathrm{B}$ and sells it short in the market for $\$ 1000$. If it separately finances bond $A$ by entering into a repurchase ("repo") agreement, then it will borrow $\$ 900$. If it executes the short sale of bond B by entering into a reverse-repurchase agreement, the firm will invest the $\$ 1000$ generated from the sale of the bond in cash which is used to collateralize the transaction. Assets are thus $\$ 1000$ of bond A plus $\$ 1000$ of cash for a total of $\$ 2000$ which implies a 20 - 1 leverage ratio. If however the firm undertakes a "borrow-versus-pledge" form of financing, it will use the $\$ 1000$ received from the sale of bond $\mathrm{B}$ to pay for bond $\mathrm{A}$ and then pledge bond A as collateral for the short position. In that case, only the equity capital, $\$ 100$, is invested in cash and total assets are only $\$ 1100$ which implies a 11-1 leverage ratio. Despite the almost halving of the measured leverage ratio, the economic position of the firm and the exposure of its creditors is identical under either approach to financing.

Accounting as a structure is directed toward value allocations. On this dimension, it is effective. We need not distinguish whether it is book or market valuation because the point here is that the accounting system basically looks only at value allocations. It is therefore, an ineffective structure for identifying risk allocations. As an example, consider a hypothetical financial institution which has fixed-rate-debt assets, floating-rate-debt financing and equity. The 
accounting system indicates the value of assets on the left-hand side, the fixedrate mortgages and on the right-hand side, it tells us what the value of deposits are as well as the value of the equity.

Suppose that this institution enters into a swap in which it agrees to receive the floating interest rate and pay the fixed rate. What is the impact of that? It is, of course, to match the risk in terms of interest-rate exposure of its assets and liabilities by transforming its floating-rate financing into fixed-rate financing, or equivalently in this case its fixed-rate returns into floating-rate returns. But where would that drastic change in the risk exposure of the equity appear in the balance sheet? An accounting structure focussed on valuations has no place for it. Why? Because the value of a swap when the firm enters into it is zero. It thus cannot be listed as a liability, and it cannot be listed as an asset.

We hear much today about so many exposures being "off the balance sheet" and it is suggested that firms which use those swaps or other offbalance-sheet contractual arrangements do so to hide information from outsiders. At times and for some firms, there may be intent in hiding it, but the major reason for these "zero-value" contractuals being off balance sheet is that the accounting system does not have a place to put them. Although such contracts have no initial value, they can have an immediate and enormous 
impact on the risk exposure of those assets and liabilities that are on the balance sheet. That is the sense in which one can say that accounting does a good job at valuation but that it is totally inadequate to deal with risk allocation which, we all understand, is one of the critical issues today. Accounting must change in a major way to address this in the future.

\section{CHANGES IN GOVERNMENT ACTIVITIES IN THE FINANCIAL SYSTEM}

I now turn to a different and topical subject: the issue of systemic-risk consequences of innovations, (especially derivatives) for regulatory and stabilization policies. As noted at the outset, innovation in general, and in particular innovations involving derivatives, holds promise for improvements to financial and economic efficiency. However, improvements in efficiency from derivative products cannot be effectively realized without concurrent changes in the supporting financial infrastructure: that is, the institutional interfaces between intermediaries and financial markets, regulatory practices, organization of trading and clearing facilities, and management information system. Developing this infrastructure may not be the most exciting part of financial innovation but it is very important.

When treated atomistically, innovations in derivative products can be implemented unilaterally and rather quickly. In contrast, changes in financial infrastructure must be more coordinated and therefore take longer to 
implement. It is therefore not surprising that revisions in accounting standards used in external risk monitoring and implementation of regulations have not kept pace with derivative-product innovations. Much the same can be said for regulations themselves. It is possible that at times the cumulative imbalance between products and infrastructure development could become large enough to jeopardize the very functioning of the financial system. Hence the need for government policy to protect against such breakdown. But, a single-minded policy, focussed exclusively on systemic-risk concerns, could derail the engine of innovation and bring to a halt the financial system's trip to greater efficiency.

Imbalances between derivative-product innovation and the evolution of the infrastructure to support it are inevitable. Government actions however can either mitigate or aggravate their disruptive effects. By analogy, hurricanes are inevitable. Government policy can either reduce their devastation by establishing early warning systems or it can aggravate the damage by encouraging the building of housing in locations that are especially vulnerable to such storms. Government action can significantly influence the path of development of financial innovation. However, successful public policy depends as importantly on recognizing the limits of what government can do to improve efficiency and on recognizing when government inaction is the best choice. 
As we all know, much has been written on whether today is such a time for government to take strong steps on derivatives to protect against a systemic event. ${ }^{12}$ That subject is surely rich enough to warrant a whole conference. I would, however, mention a few issues that perhaps should be addressed if such a conference were held.

The first of those issues is measuring the systemic-risk exposure created by derivatives. Logically, measurement should precede setting policy. One ought to know what one is seeing before deciding what to do about it. Systemic-risk exposure of derivatives must be measured relative to the risk exposure of the alternative financial structure they replace and not in some abstract, absolute terms, as if there were no systemic-risk exposure prior to their introduction.

For example, with a daily volume between $\$ 600$ billion and $\$ 1$ trillion, the inter-bank foreign exchange market appears to have a systemic-risk potential from settlement fallure. The over-the-counter (OTC) option market for foreign exchange is in part a substitute for trades in the inter-bank market. The magnitude of exposure to contract default on OTC options is related to the difference between the principal amount and the strike price. In the foreign-

\footnotetext{
${ }^{12}$ Most recently in the US, the General Accounting Office 1994 report and the Global Derivatives Study Group (1993). See also Darby (1994), Freeman (1993), and Paré (1994).
} 
exchange market, principal amounts are exchanged and so the default exposure is the total principal amount, not just the difference between the principal amount and the strike price. Therefore, although the options surely have exposure to contract default, their use as a substitute for standard foreign-exchange (forex) transaction actually reduces the magnitude of systemic exposure. Much the same point applies to the "Rolling Spot" forexfutures contract traded on the Chicago Mercantile Exchange. As with other futures markets, the default exposure there is only to the change in the principal amount between settlements. Moreover, the settlement on the future contract is once every day, not every two days as in the inter-bank market. As developed more generally in Perold (1995), this is only one example of a derivative contract which has systemic exposure from its contract-default exposure, but the contract in part replaces something that had even more default exposure. If we are going to have intelligent discussions about the systemic-risk problem of derivatives and how to deal with it, we must always measure it relative to other alternative structures that would replace, or were replaced by, derivatives. This discussion is not intended to suggest that derivatives always reduce systemic-risk exposure. It is, however, to say that one cannot tell simply by looking at the absolute exposure.

Determining appropriate relative comparisons of systemic-risk exposure is the prime measurement issue in the short run. In the longer run, as already 
indicated, financial accounting needs fundamental revisions and a specialized new branch that might be called "risk accounting." The prospect for the latter is not just hypothetical. Pressed by the reality of need, many of the financial institutions that deal extensively in these complex securities have developed risk-accounting systems as part of their managerial accounting. Those that I have seen appear to be effective and could serve as prototypes for standardized risk accounting. ${ }^{13}$

Exposure or risk accounting is going to be adapted if we are to have effective external financial accounting and regulation. Current accounting practices are focussed on valuation, which is inherently a static measure of financial conditions. Focussed on exposures, risk accounting is inherently a dynamic measure of financial condition because it indicates how the individual balance-sheet values are likely to change in response to changes in the underlying financial-economic environment.

As an illustration to contrast static and dynamic testing of financial health, consider a pension plan with a pension fund that holds assets which are there to protect or support the pension liabilities which are the retirement benefits. In the traditional accounting perspective, one looks at the value of the assets and the liabilities at a point in time and asks the question, "Are the

\footnotetext{
${ }^{15}$ While these systems are proprietary, they tend to use categorfes that reflect exposures developed in risk-management systems. For genertc examples, see Hindy (1993) and Merton (1989,242-247; 1992b,450-457).
} 
assets adequate compared to liabilities?" Let us evaluate two hypothetical cases of pension plans:

Plan A: $\quad$ It has $\$ 105$ in assets for every $\$ 100$ in liabilities, both marked to market.

Plan B: $\quad$ It has $\$ 101$ in assets for every $\$ 100$ in liabilities, both marked to market.

Based on current-valuation coverage, it looks like Plan B is less secure than Plan A. But now suppose that you are given some additional information. The assets in Plan A are held in common stocks. In Plan B, they are held in fixed-income, sovereign-backed instruments with duration matched to the promised fixed payments on the pension liabilities.

Although Plan A has a higher current coverage of assets-to-liabilities value, $\$ 105$ versus $\$ 100$, it is more vulnerable to a stock market decline and especially so if there is a crash situation in which interest rates also fall. In that case, not only do plan assets decline but the value of plan liabilities will rise and what was an excess coverage can rapidly become a deficit coverage. In Plan B, with matched funding to its liabilities, there is very little risk of that. Thus, although statically measured Plan A has greater coverage than Plan B, Plan B is seen to be more secure when dynamic tests for changes in coverage 
are applied. Again, traditional accounting focussed on current valuation cannot distinguish differences in exposures among plans. ${ }^{14}$ Risk accounting, focussed on exposures, would make their differences apparent. Over and over again we will see this happening especially as financial instruments and strategies become more complex. Exposure evaluation is one of the key developments needed in measurement.

Turning now from measurement to policy, I have just a couple of points. One is that to avoid unintended consequences, policy implementation must be comprehensive and include similar treatment of economically equivalent transactions. For example, a proposed regulation to force marked-to-market collateral requirements on all OTC derivatives, but not on loans and other traditional investments, could actually cause a shift back towards structures like parallel loans which were the functional predecessors to swaps. Parallel loans have total principal exposure, especially in cross-border trades, as well as aggregate gross interest exposure in terms of default by either party.

Swaps, which have no principal exposure, only have net interest exposure. So, by focussing and putting restrictions on derivatives but not treating other functionally equivalent alternatives that way, regulation formed with all good

\footnotetext{
${ }^{14}$ Much of the discussion surrounding the safety and soundness of the Pension Benefit Guaranty Corporation has focussed on setting static measures such as asset-surplus requirements and not on setting dynamic exposure limits. See Bodie and Merton (1993).
} 
intent and the purpose to reduce those default exposures which can induce systemic events can actually increase that exposure. ${ }^{15}$

That said, I must also say that the implementation of comprehensive regulation will be quite difficult. The point can perhaps be made most compactly by just listing the various ways of implementing a standard investment objective, and let your minds work from there.

Consider for example how many ways there are to take a levered position in the Standard and Poor's (S\&P) 500 stocks:

1. You can buy each stock individually on margin in the cash stock market.

2. You can invest in an S\&P 500 Index fund and borrow it from a bank to finance it.

3. You can go long a future contracts on the S\&P 500 .

4. You can go long an OTC forward contract on the S\&P 500.

5. You can enter into a sway contract to receive the total return on the S\&P 500 and pay LIBOR or some other standard interest rate.

6. You can go long exchanged traded calls and short puts on the S\&P 500 .

7. You can go long OTC calls and short puts.

\footnotetext{
${ }^{15}$ For example, IFR (1994) reports that the Federal Reserve is passing restrictions that could prevent banks from using the Rolling-Spot futures contract discussed earlier in this section.
} 
8. You can purchase an equity-linked note which pays based on the S\&P 500 and finance it by a repurchase agreement.

9. You can purchase from a bank a certificate of deposit which has payment linked to the return on the S\&P 500.

10. You can either buy on margin or purchase the capital appreciation component of a unit investment trust (examples are Super Shares or SPDRs) which holds the S\&P 500.

11. You can borrow to buy a variable-rate annuity contract that has its return linked to the S\&P 500 .

That is eleven ways to take the equivalent economic position of a levered position in the S\&P 500. No doubt one could probably find five more. And in the United States alone, the types of institutions involved in these functionally equivalent transactions include brokers, mutual funds, investment banks, commercial banks, insurance companies and exchanges. Again, within the US: how many regulatory authorities are involved? The SEC, CFTC, Federal Reserve, Comptroller of the Currency, and perhaps fifty State Insurance Commissions.

The point is that, in the real world, attempts to regulate just two or three of the eleven ways of doing an equivalent thing, are not going to be effective and in fact they could be counter-productive. It will be increasingly more 
difficult to regulate along traditional institutional lines in the future. To be effective in the longer run, organization of regulation must be more along functional lines instead of institutional ones. Those things that are equivalent in their economic function but are not equivalent in their institutional definitions will have to be treated the same to avoid largely ineffective, and perhaps counter-productive, regulations. The functional perspective described in Section 3 may help in defining functional regulation.

It should be noted that the eleven different forms for investing in the S\&P 500 are not simply cosmetic product differentiations among competing issuer institutions. Because of different tax and regulatory structures and other institutional rigidities, customers will not treat them as perfect substitutes. ${ }^{16}$ More generally, the flexibility created by the widespread use of contractual agreements, other derivatives, and specialized institutional designs is essential for globalization of the financial system. The financial systems of individual nation-states are rarely compatible in institutional forms, regulations, and practices. Contractual agreements are efficient means for creating interfaces among these systems. For that reason, development of this contracting technology and derivative-security markets within smaller and emergingmarket countries provide the gateway for their access to world capital markets.

\footnotetext{
${ }^{16}$ See Scholes and Wolfson (1992) and Scholes (1994) for an extensive development of this point.
} 
My last point on the issue of regulation is the central question of regulatory coordination versus regulatory competition. That question as it relates to the systemic-risk issue is: does imposition of a single regulator for all providers of a particular financial function have the unintended consequence of actually inducing a systemic-risk component that did not previously exist? Put differently: do multiple types of institutions and regulators for serving a particular financial function create multiple channels of service which thereby reduce systemic exposure?

As an analogy, consider an instance from transportation. The objective is to assure travel from England across the Channel to France. Suppose that only one institutional form of transportation across the Channel is available, flight by airplane. Assume further a single regulator for air transportation. Of course, if there is foggy weather, which is known to happen in England, then that is a systemic event. Because nothing is going to fly, it does not matter how many different airlines there are. Moreover, if the single regulator decides that planes should not fly because it thinks that there is bad weather coming and it happens to be wrong, then the single regulator actually induces the systemic event. Why not allow the Channel tunnel as another way of getting across? With a different regulator, it is in every dimension a different way to cross. Systemic risk is reduced by this diversification. But the tunnel too could block up. So why not a third way such as a hovercraft that can go 
across the surface? The likelihood that all three ways would fail simultaneously is probably quite small. Hence, by having multiple modes of transportation with different structures, one indeed reduces the systemic risk of complete breakdown in being able to cross the Channel.

As with transportation, so with financial services. However, from a regulator's point of view, regulating a particular financial function is more complicated with multiple channels of providers because now it has to deal with many different kinds of institutions. But the end objective should not be what is easiest for regulators and regulation, in the same sense that the end objective imposed by the market on those in the private sector who provide financial services is not to run their business to make it easy for themselves, but instead to be most effective for their customers.

Regulatory competition versus regulatory cooperation? It may seem from the transportation analogy as if I am suggesting a definitive answer. Not so. There truly are trade-offs on both sides. It is a key and immediate issue, especially as we hear more and more about the need for worldwide coordination of regulation and institution restrictions on the types of firms that can offer particular financial services.

On the matter of institutional changes in the government's involvement in the financial system to implement stabilization policies, I will just say 
enough to reinforce the theme set at the outset: namely, institutional change is not just for financial institutions but for central banks as well.

The increasing flexibility and global mobility of institutions, together with the derivatives technology for creating custom financial services at low costs, have far reaching implications not only for regulation but for national stabilization policies as well. Thus, policymakers are effectively speculating against the long-run trend of declining transaction costs if they assume that the traditional frictions within their individual financial system will allow nation-states to continue to pursue monetary and related financial policies with the same degree of control as in the past.

Again, permit an analogy: driving a car up a mountain side may be a very effective way to get to the top in the summer time. If, however, one tries to do it in the winter time when the friction coefficient between the road and the tires is considerably smaller, one may no longer find that it is an effective (or even feasible) way to the top. Just so, techniques for implementing stabilization policies that work in a high-friction financial environment may no longer be effective when in a low-friction environment.

On this point, consider the Stiglitz-Weiss $(1981,1988)$ theory for the way central bank activities influence macro investment in the economy. The theory holds that banks ration credit to their corporate customers and that the 
central bank through a variety of policy tools controls the banks. For the theory to apply, the customers must use the banks as essentially their sole source of capital. While not a valid assumption for large international firms with direct access to capital markets, a case can perhaps be made for smaller, "mid-market" firms, which in the aggregate are responsible for a significant portion of total investment. Even if the validity of the theory is stipulated under current conditions, how effective will this method of influencing investment be if a national mid-market lending market were created along the lines of the US mortgage market? ${ }^{17}$ Such a market would provide mid-market bank customers with access to capital from many other institutions which are not regulated or controlled by the central bank. Indeed, even without such a national market for mid-market loans, it appears that those other institutions are entering. ${ }^{18}$ Thus, the dynamics of institutional change should be an explicit element in the analysis of central banking.

In the future, central-bank and other government policymakers are likely to become increasingly familiar with financial engineering, derivatives and the advanced financial technology and concepts currently used in the private sector. They will do so not only for the apparently manifest reason of being

\footnotetext{
${ }^{17}$ See Cushman (1993).

${ }^{18}$ See Zuckerman (1994).
} 
able to better understand those parts of the financial system that they regulate, but also to perform their own financial functions more effectively. An example I have in mind involves experiments which I believe, neither the German government nor the British government intended, but nevertheless they provided. The German government in the spring and summer of 1990 issued a sizeable private placement of ten-year Schuldschein bonds with putoption provisions ${ }^{19}$. They are just like standard ten-year government bonds, except they have the feature that the holders can put them back to the government for a fixed price.

I have not discussed with anyone in the German government the reason or the intent for having added the put feature. My suspicion is that they thought they were saving money by paying a lower explicit interest rate. It is not surprising that the explicit interest rate required on a bond which guarantees a floor on its price during the ten years it is outstanding will be lower than on an otherwise identical ten-year bond that does not give such protection. But we need not concern ourselves about the intent of the issuer government. What in effect did it do by making this issue?

${ }^{19} \mathrm{I}$ am indebted to Peter Hancock and the J.P. Morgan Global Research Group for alerting me to the existence of the Schuldschiene with put options. 
By issuing those bonds, the German government introduced a preprogrammed stabilization policy. How is that? Suppose that it had issued a standard ten-year bond instead. Suppose further that afterwards interest rates start to rise, and therefore, that bond prices fall. Normal ten-year bonds would fall in price in line with interest rate rises. But what happens to the bonds with the put option? The put bonds will not decline as much as the normal ten-year. Furthermore, the rate of decline in the put bonds becomes less and less, until they cease to decline at all. At that point, they will actually begin to behave just like a short-term money instrument. In terms of "hedge ratios" or exposures relative to a normal ten-year bond, what is happening? To answer, consider a single-factor interest-rate model with dynamics described by a diffusion process. ${ }^{20}$ If $\mathrm{B}(\mathrm{t})$ denotes the price of a standard tenyear bond, then we can express the price of the puttable bonds as $F(B, t)$, where $\mathrm{F}$ is derived from a replicating trading strategy using contingent-claims analysis. ${ }^{21}$ From that analysis, the puttable bonds are economically equivalent in exposure to a portfolio of $\partial \mathrm{F} / \partial \mathrm{B}$ units of the standard ten-year bond and $[\mathrm{F}-\mathrm{B} \partial \mathrm{F} / \partial \mathrm{B}]$ invested in the shortest-maturity Treasury bill. It is straightforward to show that $0 \leq \partial \mathrm{F} / \partial \mathrm{B} \leq 1$ and that $\mathrm{F}$ is convex which

\footnotetext{
${ }^{20}$ For example, see the Cox-Ingersoll-Ross (1985) model.

${ }^{21}$ See Merton (1992b,415-419).
} 
implies $\partial^{2} \mathrm{~F} / \partial \mathrm{B}^{2}>0$. It follows that as the price $\mathrm{B}$ falls, the equivalent number of units of $\mathrm{B}$ represented by the puttable bonds, $\partial \mathrm{F} / \partial \mathrm{B}$, also falls. In effect, because of the puts, the hedge ratio or equivalent number of ten-year bonds for each put bond gets smaller and smaller as the price of the ten-year bond falls. It is thus as if government were repurchasing normal bonds. In economic effect, the government is taking the interest-rate risk back from holders as if they were purchasing bonds even though they have not actually done so. The other way around is if interest rates were to fall and bonds prices rise, then the puts would become more out-of-the-money, the equivalent number of ten-year bonds per put bond rises, and the outstanding bond exposure held by investors would increase which is effectively the same as issuing more bonds. Note that the decrease or increase in the equivalent bond exposure outstanding takes place immediately as interest rates change, without requiring that the bonds actually be put back to the government. So, whether that was the intent of the German government, in effect by issuing those put bonds they put into place an automatic stabilizer to the extent that "stabilization" means to "lean" against market movements and buy bonds when bond price goes down and sell bonds when they go up. That is, the put bonds 
function as the equivalent of a dynamic, "open-market," trading operation without any need for actual transactions. ${ }^{22}$

The put bonds do more than that because their issue also in effect announces a prescribed open-market policy. By looking at the size and terms of government put issues, the market can figure out what the implied stabilization policy is.

In comparison to traditional open-market activity, the put-option-bond automatic stabilizer should work very well over weekends, over non-trading days, and over crashes, especially when trading is going on around the world because the central bank does not have to be on the scene to do the openmarket operations. It automatically "kicks in" as soon as events occur because it is built into the structure of the securities.

I mentioned at the outset that the stated interest rate to be paid by the government on these put bonds is lower than on a standard-ten-year bond. That is because of the value of the put. This provides another difference between selling put bonds to the market and just doing the open-market stabilization policy. The government in effect is charging for the stabilization insurance because the private sector is paying for the put option rather than

\footnotetext{
${ }^{22}$ In the usual applications, the contingent-claim instrument is given and a dynamic trading strategy is derived which replicates the payoffs to the claim. Here, we start with a trading strategy and derive the contingent claim which replicates the payoffs from the strategy. This reverse approach was used by Cox and Huang (1989) to solve the lifetime consumption problem. See also Merton (1992b,457-467).
} 
receiving it for free. When I say for "free" of course, someone (e.g., the taxpayer) is paying for it.

To charge explicitly for stabilization may or may not be an intent or objective that policymakers want to achieve. It is however now feasible to charge the private sector for interest-rate insurance in an efficient way. In effect, by issuing the bonds, the government places into the private sector a positive supply of interest-rate insurance, which could then be distributed by the private sector. As I have indicated, this was probably not the conscious intent of the government. Nevertheless, once having seen it, one can view it going forward as an alternative to traditional stabilization policies and think of this as an instance of a general class of new techniques for dealing with a lowfriction, global financial system. As exemplified here, sometimes unanticipated and unintended consequences of government actions can indeed be positive. By the way, there is an example in the United Kingdom with much the same result. The government issued gilts that are convertible from short term into long-term maturities. This produces much the same policy as in the German case. It is immediately evident that the same approach to automatic stabilizers could be used with respect to automatic intervention programs for currencies.

All of this does not address the question of whether governments should pursue stabilization. But if it remains a part of government policy, I predict that central banks will employ derivative instruments to do so. It appears to 
be a much more effective way than the traditional methods of undertaking dynamic trading in an effort to simulate what can be achieved from issuing a derivative instrument. 
Robert C. Merton

\section{REFERENCES}

Allen, F. and D. Gale (1994), "Financial Innovation and Risk Sharing," Cambridge, MA: MIT Press.

Bernstein, P.L. (1992), Capital Ideas: The Improbable Origins of Modern Wall Street, New York: Free Press.

Bodie, Z. and R.C. Merton (1993), "Pension Benefit Guarantees in the United

States: A Functional Analysis," in R. Shmitt, eds., The Future of Pensions in the United States, Philadelphia: University of Pennsylvania Press.

Cox, J.C. and C. Huang (1989), "Optimum Consumption and Portfolio Policies When Asset Prices Follow a Diffusion Process," Journal of Economic Theory, 49(October):33-83.

Cox, J.C., J.E. Ingersoll, and S.A. Ross (1985), "A Theory of the Term Structure of Interest Rates," Econometrica, 53(March):385-408.

Crane, D. et al. (1995), The Global Financial System: A Functional Perspective, Boston: Harvard Business School Press.

Cushman, Jr., J.H. (1993), "Investing in Loans to Businesses," New York Times, March 19, Section D. 
Darby, M. (1994), "Over-the-Counter Derivatives and Systemic Risk to the Global Financial System," National Bureau of Economic Research Working Paper \#4801, Cambridge, MA (July).

Finnerty, J.D. (1992), "An Overview of Corporate Securities Innovation," Journal of Applied Corporate Finance, 4(Winter):23-39.

Freeman, A. (1993), "A Survey of International Banking: New Tricks to Learn," The Economist, April 10:1-37.

General Accounting Office (1994), Financial Derivatives: Actions Needed to Protect the Financial System, Report GAO/GGD-94-133, Washington, D.C. (May).

Global Derivatives Study Group (1993), Derivatives: Practices and Principles, Washington, D.C.: The Group of Thirty (July).

Grossman, S.J. and O.D. Hart (1982), "Corporate Financial Structure and Managerial Incentives," in J.J. McCall, ed., The Economics of Information and Uncertainty, Chicago: University of Chicago Press.

Hindy, A. (1993), "Elements of Quantitative Risk Management," Graduate School of Business, Stanford University (May).

IFR (1994), "US Derivatives: Fed Stance May Jeopardize Rolling Spot," International Financing Review, February 19. Jensen, M.C. (1986), "Agency Costs of Free Cash Flow, Corporate Finance, and Takeovers," American Economic Review, 76(May):323-329. 
Kopeke, R.W. and E.S. Rosengren, eds. (1990), Are the Distinctions Between Debt and Equity Disappearing? Conference Series \#33, Federal Reserve Bank of Boston.

Mason, S., R.C. Merton, A.F. Perold, and P. Tufano (1995), Casebook in Financial Engineering: Applied Studies of Financial Innovation, Englewood Cliffs, NJ: Prentice-Hall.

Merton, R.C. (1989), "On the Application of the Continuous-Time Theory of Finance to Financial Intermediation and Insurance," The Geneva Papers on Risk and Insurance, 14(July):225-262.

Merton, R.C. (1992a), "Financial Innovation and Economic Performance," Journal of Applied Corporate Finance, 4(Winter):12-22.

Merton, R.C. (1992b), Continuous-Time Finance, Revised Edition, Oxford: Basil Blackwell.

Merton, R.C. (1993), "Operation and Regulation in Financial Intermediation: A Functional Perspective in P. Englund, ed., Operation and Regulation of Financial Markets, Stockholm: The Economic Council.

Merton, R.C. (1994), "Influence of Mathematical Models in Finance on Practice: Past, Present and Future," Philosophical Transactions of the Royal Society of London, 347(June):451-463. 
Merton, R.C. and Z. Bodie (1993), "Deposit Insurance Reform: A Functional Approach" in A. Meltzer and C. Plosser, eds., Carnegie-Rochester Series on Public Policy, 38(June).

Merton, R.C. and A.F. Perold (1993), "Theory of Risk Capital in Financial Firms," Journal of Applied Corporate Finance, 5(Fall): 16-32.

Miller, M.H. (1991), Financial Innovation and Market Volatility, Oxford: Basil Blackwell.

Paré, T.P. (1994), "Learning to Live with Derivatives," Fortune, July 25:106-1 16.

Perold, A.F. (1992), "BEA Associates: Enhanced Equity Index Funds," Harvard Business School Case \#N9-293-024, Boston, MA (August).

Perold, A.F. (1995), "The Payment System and Derivative Instruments," in Crane et al. (1995).

Pierce, J.L. (1993), "The Functional Approach to Deposit Insurance and Regulation," in R. Randall, ed., Safeguarding the Banking System in an Environment of Financial Cycles, Conference Series \#37, Federal Reserve Bank of Boston.

Sanford, C. (1993), "Financial Markets in 2020," in Proceedings of Federal Reserve Bank of Kansas City Economic Symposium, August. 
Scholes, M.S. (1994), "Financial Infrastructure and Economic Growth," Conference on Growth and Development: The Economics of the 21st Century, Center for Economic Policy Research, Stanford University (June).

Scholes, M.S. and M.A. Wolfson (1992), Taxes and Business Strategy: A Planning Approach, Englewood Cliffs, NJ: Prentice-Hall.

Stiglitz, J. (1988), "Money, Credit, and Business Fluctuations," The Economic Record, 64(December):307-322.

Stiglitz, J. and A. Weiss (1981), "Credit Rationing in Markets with Imperfect Information," American Economic Review, 71 (June):393-410. Zuckerman, L. (1994), "Junk Loans, Not Bonds, are Hot on Wall Street," New York Times, August 31:D1. 